Kaygı, 18(1)/2019: 172-187. Araştırma Makalesi | Research Article

Makale Geliş | Received: 25.12.2018

Makale Kabul | Accepted: 10.02.2019

Yayın Tarihi | Publication Date: 15.03.2019

DOI: 10.20981/kaygi.529827

Ferhat BAYIK

Doktora Öğrencisi | PhD Candidate

Akdeniz Üniversitesi, Edebiyat Fakültesi, Felsefe Bölümü, Antalya, TR

Akdeniz University, Facutly of Literature, Department of Philosophy, Antalya, TR

ORCID: 0000-0001-5924-2512

ferhatbayik@hotmail.com

\title{
Aristoteles ve Descartes Bağlamında Akıl ve Zekâ Kavramlarının Farkları
}

\section{$\ddot{O} \mathbf{z}$}

Akıl Nedir? Zekâ Nedir? Bu kavramlar arasındaki ayrım ve ilişki ne olabilir? İnsanın neliğini belirleyen akıl ve zekâ hakkındaki bu evrensel sorular, zihnin tarihsel evrimi bağlamında önemlidir. Bu eksende çalı̧manın amacı; akıl ve zekâ kavramlarının mahiyetini özellikle Aristoteles ve Descartes temelinde ele alarak arasındaki farklılıkları, benzerlikleri, kullanım alanları ve bu kullanıma bağlı olarak her iki kavramın da insan etiği açısından doğuracağı muhtemel felsefi sonuçları ortaya koymaktır. İlkçağ felsefesinde önemli bir kavram olan akıl (logos) sözcüğü özellikle Aristoteles tarafından zihin-beden birliği bağlamında bütün boyutlarıyla temellendirilmiștir. Ancak, modern felsefenin ilkelerini ortaya koyan Descartes'in zihin ve bedeni kökten ayırmasıyla, yepyeni bir zekâ anlayışı ortaya çıkmıștır. Kartezyen bilincin, akıl kavramını zekâya indirgenmesi bu anlayışın en önemli doğurgusudur. Aristoteles'ten Descartes'e değin tarihsel ve felsefi gelişmeler düşünüldüğünde, akıl ve zekâ bir üçgenin kenarlarına benzetilebilir. Akıl üçgenin geniş tabanını oluştururken, daralarak sivrilen kısım ise zekâdır. Üçgenin geniş tabanı aklın barındırdığı engin anlamı temsil ederken, sivrilerek yukarı çıkan zekâ ise hem aklın anlamını daraltır hem de onun görevini üstlenircesine yükselir. Yükselmesine bağlı olarak daha keskin, daha sivri ve daha dar bir açı oluşturur. $\mathrm{Bu}$ yönüyle düşünüldüğünde insani nitelikleri etraflıca ortaya koyabilmenin ön koşulu Kartezyen zekâ değil, Aristotelesçi akıl kavramıdır.

Anahtar Kelimeler: Aristoteles, Descartes, Ak1l, Zekâ, Logos, Nous.

\section{The Differences Between Mind and Intelligence in Aristotle and Descartes}

\section{Abstract}

What is Mind? What is intelligence? What are the distinction and relationship between these concepts? These universal questions about the mind and intelligence that determine human wholeness are important in the context of the historical evolution of the mind. Concerning these questions, the aim of this study is to reveal the differences, similarities, domains of use and the possible philosophical consequences of both concepts regarding human ethics especially through perspectives of Aristotle and Descartes. The word mind (logos), which is an important concept in ancient philosophy, had been grounded with all dimensions by Aristotle's mind-body unity. However, a new understanding of intelligence which reveals the principles of modern philosophy has emerged with Descartes. Degrading "mind" into "intelligence" is the most important outcome of Cartesian understanding. From Aristotle to Descartes, when historical and philosophical improvements are considered, mind and intelligence can be compared to the edges of a triangle. Mind constitutes the broad base of the triangle, while the narrowing top part refers to intelligence. While the wide base of the triangle represents the vast meaning of mind, the spiring intelligence both narrows the meaning of mind and rises up to take over the role of mind. Due to its elevation, it creates a sharper, more pointed and narrower angle. Considering this aspect, the prerequisite of revealing human qualities is not the Cartesian intelligence, but the Aristotelian mind.

Keywords: Aristotle, Descartes, Mind, Intelligence, Logos, Nous. 
Kavramların mahiyetini etraflıca ortaya koymak felsefenin önemli önceliklerindendir. Bu önceliği bize düşündüren, sorgulatan hatta ondan kuşkulandıran şeyin akı1 ${ }^{1}$ veya zekâ ${ }^{2}$ olduğu fikri yaygındır. Aristoteles "Bütün insanlar doğal olarak bilmek isterler." (Ross 1908: 2205) ifadesiyle bilginin ve bilme eyleminin önemine Metafizik kitabının girişinde dikkat çeker. Akıl ve zekâ bilginin işlendiği ve bilme eyleminin gerçekleştirildiği alandırlar. Bu yönüyle her iki kavram da birçok yerde eş anlamlarda kullanılmaktadır. Öyle ki, çeşitli dillerin sözlüklerinde dahi her iki kavram tam anlamıyla ayırt edilememekte ve birbirleri yerine kullanılabilmektedir. Örneğin:

Türkçe'de "akıl” için düşünme, anlama ve kavrama gücü, us; "zekâ" için insanın düşünme, akıl yürütme, objektif gerçekleri algılama, yargılama ve sonuç çıkarma yeteneklerinin tamami, anlak, dirayet, zeyreklik, feraset.

İngilizce'de akıl (mind) için; hatırlama ya da hatırlanma durumu, zekâya ait işlerin yapıcısı, kişinin zihinsel etkinlikler kapasitesi, entelektüel kalite, zihinsel güç. Ayrıca zekâ, beyin, ruh, kıvrak zekâ anlamlarına gelen intellect, soul, psyche, brain, brains, intelligence, wit sözcüklerinin eş anlamlısı olarak verilmiş insanın algılama, hatırlama, tasarlama, değerlendirme ve kararlaştırma gibi özellikleri içeren karmaşık fakültesi olarak tanımlanmıştır. Zekâ (intelligence) için; anlama fakültesi, bilme veya kavrama kapasitesi, bir kişinin yeni ortama uyum sağlama, problem çözebilme, öğrenme, sembolleri ya da ilişkileri kullanabilme gibi niteliklerin zekâ testleriyle ya da diğer sosyal kriterlerle ölçülmüş mevcut becerileri (Websters 1986: 1174, 1436).

Fransızca'da akıl (esprit) için; ruh, hayati nefes, akı1, duyu, anlayış, zekâ, zekâ kıvraklığı... Zekâ (intelligence) için; zekâ, akıl; açıkça anlama veya anlama, beceri, yetenek; karşılıklı anlayış ilişsisi, yazışma, bilgi aracı (Girard 1965: 316, 427).

Almanca'da akı1 (geist) için; zihin, akıl, düşünme yeteneği; zekâ. Zekâ (Intelli'genz) için; zekâ, akıl. İnsanın, duyguları bilme ve akılla kontrol etme yeteneği. (Ülkü 2006: 317, 415).

İspanyolca'da Akıl (mente) için; akıl, zihin, us, niyet, düşünüş, idrak irade. Zekâ (inteligencia) için; anlaşılma, kavranma, anlama kapasitesi, kavrama yeteneği zekâ. (Uriarte vd. 2010: 788, 843).

Yukarıdaki tanımlardan fark edileceği üzere, gerek akıl gerekse zekâ kavramları arasındaki biricik ayırıcı unsur net olarak verilememiştir. Hatta birbiriyle özdeş sözcükler her iki kavramın tanımı bağlamında yinelenmiştir. Bunun nedeni Aristoteles'in akıl anlayışından ziyade Descartes'in bilinç anlayışı ekseninde

\footnotetext{
${ }^{1}$ Alm. Geist, İng. mind, İsp. ment, Fr. esprit.

${ }^{2}$ Alm. Intelligenz, İng. intelligence, İsp. inteligencia, Fr. intelligence.
} 
kavramların şekillendirilmesidir. Bu müphemlik Aristoteles'in akıl kavramına getirdiği bütüncül bakış açısının anlaşılmasıyla giderilebilir. Bu uğurda, Descartes'in bilinç anlayışı etraflıca ele alınarak, zekâ kavramının akıldan hangi bakımdan farklı olduğu anlaşılacaktır.

Soyut kavramlar oldukları için akıl ve zekâ üzerine net tanımlar getirmenin güçlüğü ortadadır. Dolayısıyla akıl ve zekânın farkı, konumu, arasındaki ilişkinin anlaşılması filozofların yorumlarıyla mümkün hale gelebilecektir. Örneğin, ilkçağ düşünürlerinin zekâ sözcüğü yerine doğrudan kullandıkları bir tabir yoktur. Bunun yerine akıl, zihinsel ve bedensel olguların bir bütünü olarak zekâyı ilgilendiren fakülteleri de kapsar. Ancak, zekâ kelimesine denk gelen bir alan olduğu düşünülebilir. Sezgisel akıl (nous) Aristoteles'in etkin ve edilgin olarak kendi içinde ikiye ayırdığı bir alandır. Bu alan, Descartes'in bilincine yani zekâya en yakın nitelikler barındırmaktadır. Kavram karmaşasına mahal vermemek adına, bu noktadan itibaren akıl için logos sözcügü kullanılacaktır. İlkçağ anlayışında logos ilahi niteliği olan, tarihsel, kapsayıcı ve duyulardan beslenen bir olgudur. Oysa zekâ bu bütünselliğin içinde küçük bir alandan ibarettir. Çağdaş dünyada kullanılan zekâ sözcüğünün kökeni 17. Yüzyıl felsefi anlayışına özellikle Descartes'in zihin-beden görüşüne dayanır. Yani özellikle bu dönem sonrasındaki gelişmeler, zekâ teriminin bugünkü manasıyla kullanılmasına neden olmuştur. Hatta öyle bir noktaya gelinmiştir ki, zekâ sözcüğü akıl karşısında yüceltilerek insani değerler zekâ ölçütüne indirgenmiştir. Bunun için çeşitli testler dahi geliştirilmiştir. Bu denli iç içe geçmiş ve birbirinin yerine kullanılan bu iki sözcük günümüz anlayışında ciddi kavramsal yanlışlıklara neden olabilmektedir. İnsan aklı salt bir organa özgü bir şey olmamakla birlikte, bir organın parçası olarak da düşünülmemelidir. Tam tersine akıl tarihselliği olan, alt unsurlara sahip kapsamlı bir olgudur. Bu yönüyle akıl salt hesaplama, işleme, kıyaslamadan yani zekâ olarak tabir edilen alandan ibaret değildir. En öz tabiriyle insani nitelikleri olduğu gibi ortaya koyabilen kavramın kendisidir akıl. Zekâ ise yalnızca belirli alanlara özgü kabiliyetleri etkin bir şekilde ortaya koyabilme becerisidir. 
Yukarıda sözünü ettiğimiz iddiaların temelini Aristoteles'in bilgiyi ve bilme eylemini zihin-beden birliğinde gerçekleşen bir olgu kabul etmesi oluşturur. Çoğu yerde akıl ve ruh sözcükleri birbiriyle özdeşleştirilir ve birbirinin yerine kullanılır. Öyle ki ruh (psyche) Aristoteles için akılsal fakültelerin tümünü barındıran bir çember ya da taşıyıcıdır. Ruha ait olan akıl da kendi içerisinde çeşitli kısımlara ayrılır. Her bir kısım, bilgiye ulaşma uğrunda farklı görevlerin icra edilmesinden sorumludurlar. Aristoteles aklı akıl yapan unsurları yani, aklın doğru bilgiye ulaşma yöntemlerini beş yolla sıralar; sanat (techne), bilimsel bilgi (episteme), pratik bilgelik (phronēsis), felsefi bilgelik (sophia) ve sezgisel akıl (nous). (Aristotle 1893: 184). Bu noktada akı1, sözünü ettiğimiz bu beş alandan meydana gelir. Aristoteles, bu kavramlardan her birinin çeşitli görevlerini bazı eserlerinde belirtir. Öyle ki, doğru bilgiye ulaşma yolunda pratik bilgelik pratik bilgelik (phronēsis) ve sezgisel akıl (nous) insani nitelikleri doğrudan belirlediği için önemlidir. Bu sebeple, Aristoteles'in sezgisel akıldan (nous) önemle bahsetmesi, gerek zekânın temelini oluşturması açısından gerekse ilahi özellikler barındırması açısından dikkat çekicidir.

Sezgisel aklın (nous) detaylarını Aristoteles etkin ve edilgin akıl başlığı altında açıklar. (Ross 1995: 93). Sezgisel aklı (nous) etkin ve edilgin olarak ikiye ayıran Aristoteles için salt akılsal nitelikler sadece etkin olan bölüme münhasırdır. Edilgin akıl sadece bedenin duyular vasıtasıyla aldıklarını işler. Diğer bir deyişle edilgin bölüm, kendine sağlanan bir veri olmaksızın herhangi bir işlem yapamaz. Bu yönüyle düşünüldüğünde her insanın farklı bedeni olduğu gibi, farklı edilgin akıllar da mevcuttur. Çeşitli edilgin akıllar bedene bağlı olarak ortaya çıkar ve yok olurlar. Gökberk'e göre Aristoteles'in bu yorumu bireyin ölümsüzlüğünü benimsemediğini ortaya koyar. Oysa etkin akıl bedenden ve dünyasal şeylerden tamamen farklıdır ve yaratılmadığı gibi yok da olmayacaktır. (Gökberk 1993: 87).

Bu konu üzerine Ross'un (1995) yorumuna bakıldığında asıl ve ilk olarak var olan edilgin akıldır. Etkin akıl, yalnızca edilgin aklın potansiyelini ortaya çıkaran şey yani bir nevi kıvılcımdır. Burada önemli bir husus da etkin ve edilgin akıl ayrımının ruh 
içinde bulunmasıdır. Bazı düşünürlere göre etkin akıl ruh dışında konumlanan ilahi bir akıldır. Ancak, Aristoteles Metafiziği'nde de belirttiği gibi etkin akıl insan ruhuna içkin ilahi bir akıldır. "Bu, faal aklı bireysel insani varlı̆̆ın tümüyle dışında bulunan Tanrısal bir akla özdeş kılmaya çalışan her türlü yorum imkânını ortadan kaldırır, ama faal akılda insan ruhuna içkin bir Tanrısal aklı gören yorumu ortadan kaldırmaz." (Ross 2011: 235). Etkin aklı insani varlığın dışında konumlandırarak, onu Tanrısal bir akılla eşit tutma düşüncesi bu durumda boşa çıkmaktadır. Ancak, insan ruhu içerisinde içkin bir Tanrısal aklın varlığını savunmak Aristoteles'e göre doğru bir yaklaşımdır. Burada amaç, Tanrı'nın mahiyetini belirlemede faal aklın bir araç olarak kabul edilmesi anlamına gelir ama faal aklı tek başına bir Tanrı düşüncesiyle eşdeğer tutmaz. Aksi halde, Tanrı insan ruhunda bulunan bir şey olması gerekir. Bu düşünce Aristotelesçi Tanrı anlayışına terstir. Aristoteles'in özellikle İlk Hareket Ettirici (Prime Mover) hakkındaki bölümünde, Tanrı'dan hareket etmeyen hareket ettirici olarak bahsedilir (Ross 1995: 95). Bu anlayışa göre, birbirine benzeyen yani homojen anlamda dünyevi kuvvelerin ötesinde Tanrı, heterojen bir kuvveye sahiptir. Bu yönüyle kendisi hareket etmeyen ancak öteki şeyleri hareket ettirebilen masif bir olgudur. Dolayısıyla, Tanrı idesi Aristoteles'e göre etkin akıl (active intellect) edilgin akıl (passive intellect) ya da bunların genel adı sezgisel akla (nous) eşdeğer bir şey değildir. Bunların ruh altında konumlandırılması koşuluyla, Tanrı'yı anlayabilme yolunda araç olarak kabul edilmesi mümkündür. Daha öz bir ifadeyle Aristoteles için etkin akıl, edilgin akıl (zekâ) ile nesne arasında bir aracı değildir.

Bilginin olgusal gerçeğini anlamak istiyorsak, pasif akıl ve nesne arasındaki ilişkinin yanı sıra, etkin akıl bir aracı olmamasına rağmen yine de üçüncü bir şeydir. Görme yetisinin olgusal gerçeğini anlayabilmek istiyorsak, göz ve nesne arasındaki ilişkide olduğu gibi 1şık da üçüncü bir şey olarak ele alınmalıdır. Işık, bir aydınlatıcı olarak aslında şeffaf hale getirilmiş bir ortamın aracı koşuludur ve aslında görebileceğiniz gözün ve görünür nesnenin görülmesini mümkün kılan şey 1şığın gerçekliğidir ya da aktüalitesidir (Ross 1995: 156).

Aristoteles Nikomakhos'a Etik eserinde makul olanı az ya da çok değil ikisinin ortası olarak işaret eder. Ona göre orta olan şey de doğru akıldır. Bu görüşünü pratik 
akıl (phronēsis) için de savunur. Akıl, aşırı ve yetersiz olanın arasında bulunan ortayı yakalamayı amaçlar. Pratik akıl (phronēsis) de insan eylemlerinde daima ölçülü olanı yakalamayı amaçlar. Türkçe karşıllı̆ı aklıselim olan phronēsis, nous'tan farklı olarak deneyimi ve tecrübeyi yönetir. Yani akıl sahibi olmak, aklıselim olmak ya da aklı başında olmak ancak yaşantılarla ve deneyimlerle mümkündür. $\mathrm{Bu}$ bağlamda Aristoteles; "Dahası, bir insanın kendi sorunlarıyla başa çıkabilmesi inişli çıkışlı bir yoldur ve dikkat gerektirir. Bu durum, bir gencin geometride ya da matematikte ustalaşabileceği ve bu konularda bilge olabileceği ama onun ihtiyatlı ya da sağduyulu olamayacağı gerçeğinden anlaşılmaktadır. Bunun sebebi, bazı gerçekleri bize sadece deneyim tanıtabilir ve nihayetinde insan ihtiyatlı veya sağduyulu olabilir; ama genç birisi yılların meyvelerini tatmadığı için deneyimsiz olmalı." (Aristotle 1893: 194). ifadesiyle akıl kavramını salt uslamlamaya indirgemez. Tersine, aklıselim (phronēsis) sözcüğünü, deneyim ve zamanla ilgili olduğu için yüceltir. Çünkü aklıselim olmak başlı başına kısa süre içerisinde, belirli uslamlamalarla oluşturulabilecek bir şey değildir. Dolayısıyla, Aristoteles'in anlayışına göre, genç birisi rasyonel anlamda zeki olabilir ancak aklıselim olmak, yılların meyvesini tatmış deneyim ve tecrübe sahibi kişilere özgü bir olgudur. Bunun yanı sıra pratik akıl (phronēsis), arka planda mutluluk gayesini taşır. $\mathrm{Bu}$ sebeple Aristoteles, "Aklıselim dediğimiz insan sağlık, para, güç gibi ayrıntılarla değil iyi yaşama konusunda kendisine nelerin gerekli olduğunu doğru bir şekilde düşünebilen insandır (Aristoteles 2014: 132). demiştir. Bu yönüyle pratik akıl da sezgisel akıl kadar önemli ve insani nitelikleri doğrudan konu alır. Pratik akıl (phronēsis) ve sezgisel aklın (nous) yanı sıra, yukarıda sözünü ettiğimiz bilimsel bilgi (episteme), sanat (techne), felsefi bilgelik (sophia) kısımları da ruhun yani aklın diğer kısımlarıdır.

Aklın, sanat fakültesi (techne) söz konusu olduğunda, yapma ve yaratma sözcükleri öne çıkar. Öyle ki, yapma ve yaratma birbirinden farklıdır. Bir şey, ilk halinden farklı bir durumdaysa o şey ya yapılmıştır ya da yaratılmıştır (to do / to make). Ortaya çıkan her şey bir sanat değildir. Örnek olarak, mimarlık; yaratmanın akılla ilgili bir unsurudur. Öyle ki, her bir sanat zorunlu olarak yaratmayla ilgilidir. Bunun koşulu 
da yaratan insandır. Sanat yalnızca doğru akılla eşzamanlı bir yaratma eylemidir. Bu yönüyle bir yapma değildir (Aristoteles 2014: 132). Ross'un daha öz bir ifadesiyle sanat, doğru bir kural aracılığıyla şeyleri meydana getirme ya da yaratma eğilimidir (Aristotle 1893: 225). Burada sözü edilen doğru kural, aklı kasteder bu da sanatın aklın bir uzantısı olduğunu doğrudan vurgulamaktadır.

Bilimsel bilgi (episteme), öğretim yoluyla aktarılabilen gerekli ve sonsuz olan şeylerle ilgilidir. Öğretim her zaman bilinen ile başlar ve tümevarım ya da kıyas ile ilerler. Ancak tümevarım bilimsel bir süreç değildir; bilim olan kıyas sürecinin ilerlediği ilk ilkeleri sağlar. Bilimsel bilgi, bir şeyi ispatlayabilme yeteneğimizdir (Aristotle 1893: 224).

Felsefi bilgelik (sophia), sezgi ve bilim bileşkesinin en yüksek nesnelerde yoğunlaşması olarak anlaşılabilir. En yüksek gök cisimlerinin konumu ne ise, felsefi bilgeliğin konumu da pratik bilgeliğe kıyasla odur. Felsefi bilgelik, Metafizikte kabul gören matematik, metafizik ve doğa bilimini kapsamaktadır. Aristoteles'e göre bu konular özellikle insanın amaçladığı en iyi yaşamın bir göstergesi niteliğindedir. (Ross 2011: 339).

Yukarıda sözünü ettiğimiz sanat (techne), bilimsel bilgi (episteme), pratik bilgelik (phronēsis), felsefi bilgelik (sophia) ve sezgisel akıl (nous) fakültelerine logos ev sahipliği yapar. Bu yönüyle logos sadece insanı diğer tüm hayvanlardan ayırmakla kalmaz, aynı zamanda insan ruhunu kendi içinde ayırır. Aristoteles'in akıl anlayışının temelinde bütünsellik diğer bir ifadeyle birlik yatar. Ona göre beden ve zihin birbirinden ayrı düşünülemez. Bu konuya ilişkin Thomas Aquinas'ın yorumu önemlidir. “Aristoteles'te bulunmamakla birlikte Aristotelesçi bir prensip olan 'daha önce duyularda bulunmayan hiçbir şey kavrayışta bulunmaz' (nihil est in intellectu, quod non prius fuerit in sensu) ifadesi akıl ile bedenin birliği görüşünü modern zamanlara kadar sürdürür." (Kelly 2017: 108). Logos bir bakıma bu bütünselliği oluşturan bedensel ve zihinsel olanların kapsayıcı alanıdır. Aygün'ün ifadelerine bakıldığında logos'un bedensel ve zihinsel şeylere nüfuz ettiğine ancak kendi içinde bu olguların tamamıyla 
logos'a teslim olmadığı, kendi içinde de logos'a sahip ve logos'tan yoksun alanlar olduğu anlaşılmaktadır:

Şu an için hem dünya hem de insan ruhu bir şekilde logos ile donatılmış gibi görünür, ama hiçbiri tepeden tırnağa donatılmış değildir. Yine de insan ruhunun analizi, alogos kısmı ile logos olan kısım arasındaki ayrımın ötesinde bir ayrım daha gerektirir. Örneğin, beslenme ve büyüme sadece alogos'a özgüdür. Ancak bu alogos bölümünün yanı sıra logos'a sahip olan insan ruhunun başka bir parçası daha var. Bu üçüncü bölüm, ikisi arasında bir şekilde aracılık etmektedir: "alogos" iken, bir şekilde logos'a katılır (Aygün 2017: 116-117).

Diğer bir yönüyle, logos sözcüğü çeşitli anlamlarda ve görevlerde kullanılmıştır. Yunanca isim kökünden gelen logos, klasik dönemlerde kullanılan lego (söylüyorum) fiilinden türemiştir. Günümüz sözlüklerinde başlıca; kelime, konuşma, argüman, açıklama, doktrin, itibar, sayısal hesaplama, ölçü, oran, ifade, prensip ve akıl gibi sözcükler logos'un standart anlamlarıdır. Daha sonraları, Stoa felsefesini derinden etkileyecek olan Heraklitos'un logos doktrini üç temel anlamda kullanılır; evren hakkındaki düşüncelerimiz, evrenin kendi rasyonel yapısı ve bu rasyonel yapının kaynağı. Heraklitos logos'u bir akıl türü olarak görse de başlı başına bir düşünme etkinliği olarak görmemiştir. Anaksagoras ise bu tartışmayı bir adım daha ileri götürerek evrenin akıl prensibini ortaya koyar. Ona göre akıl logos'tan ziyade nous 'tur ve öteki şeylerden özerk bir haldedir. Sofistlere bakıldığında logos, argümanlar ve argümanların neyle ilgili olduğu hakkında kullanılır. Böylece 'doğru akıl' orthos logos hem doğru argüman, kuram hem de bu kuramın ya da argümanın neyle ilgili olduğunun yapısını oluşturan şeydir. Platonik evrene bakıldığında, onun rasyonel ilkelerle organize edildiği görülür. Ancak, bu organizasyon ya da düzen sezgisel akıl (nous) ile şekillendirilir. Ancak, insan ruhu söz konusu olduğunda Platon özellikle, Devlet eserinde nous ve logos'u çok yakın anlamlarda kullanır. Stoacı düşünce sisteminde, logos doktrini en geniş uzantısına erişmiştir. Bu yönüyle logos Stoalılar için evrendeki bütün aklın ilkesidir. Öyle ki, logos bütün etkinliklerin kaynağı olan Tanrı’yla tanımlanmıştır. $\mathrm{Bu}$ düşünceye göre $\operatorname{logos}$, diğer maddelerin içine işleyen bir başka 
maddedir. Öz bir ifadeyle, logos; bir şarap damlasının bütün denizin her yerine yayılarak nüfuz etmesidir. (Kerferd 1967: 83).

Stoalıların Tanrı anlayışına derin etkisi olan Heraklitos'un logos yorumu, Stoalıların Tanrı'dan şüphe ettiği ve çıkmaza girdikleri durumunda başvurdukları ilk kaynak olmuştur:

Heraklitos'a göre logos işitilen, şeyleri açıklayan, her şeye ortak olan bir şeydir. Onun bir diğer kavramı da uyumdur (harmony). Herakleitos dünyayı, her şeye ortak olan logos tarafindan birleştirilmiş ve düzenlenmiş şeylerin bir koleksiyonu olarak görür. Ona göre dünyayı düzenli yani uyumlu bir yapıya, bir kozmosa dönüştüren şey logos'tur. Bu nosyon da Stoacı evren anlayışında çok önemli bir yere sahiptir. Stoalılar Herakleitos'un uyum kavramını benimsemeseler de herkesçe paylaşılan, her şeyi yönlendiren logos anlayışını benimsemişlerdir. Logos'un sembolü ya da aracı olan ateş de Stoa fiziğinin temeli olarak Zeno tarafindan kanıksanmıştır. Her şeyden önce, Stoalılar logos'un sistematik olarak yönettiği bir evrenin dilsel ve mantıksal etkilerini geliştirmiş̧lerdir. (Long 1986: 145-146).

İfadelerden anlaşılacağı gibi Stoalılar logos sayesinde evreni açıklamaya ya da somutlaştırmaya çalışmışlardır. Akı1 için en kapsayıcı sözcük olan logos da tıpkı nous gibi ilahi bir Tanrı'yla eşdeğer tutulmuştur. "Stoacı evren, bir yasa tarafindan yani içkin (immanent) bir logos tarafından belirlenen bir dünyadır. Bu onların felsefesinin her üç yönünden geçer. Sonuçta, bunlar sadece yönlerden ibarettir yani başka çıkar yol olmadığında birliği (unity) - doğa, evren ya da Tanrı olan bir şeyi sunmanın yollarıdır." (Long 1986: 144). Logos sözcüğü aklın bütün fakültelerini kapsadığı için, tümelin bilgisini vermektedir. $\mathrm{Bu}$ nedenle ilahi bir anlam yüklenmesi o dönemin çaresizliğinde gerek Heraklitos gerekse Stoacılar tarafından başvurulan bir seçenektir. Bu durumda logos Tanrı'nın kendisinden ziyade aklın bütün fakültelerini içine alan çemberdir.

Daha yakın bir zamanda Wedin, baskın bir görüşle logos'un temelde bir fakülte olduğu kadar dil olduğu sonucuna varmıştır. Corpus'taki çoğu pasajın logos'u dil (language) ile bağdaştırdığını, hatta De Partibus Animalium II. 17, 660a2-3 eserinde logos'un ses yoluyla harflerin birleşiminden oluştuğunu söyler. De Generatione Animalium V.6, 786b19-22 eserinde doğanın insanı en çok ses kapasitesiyle donattı̆̆ını, çünkü hayvanlar içinde yalnızca onun logos'u kullandığını bildirir. Yine, Politica I.2, 
Ferhat BAYIK, “Aristoteles ve Descartes Bağlamında Akıl ve Zekâ Kavramlarının Farkları," Kaygı, 18(1)/2019: 172-187.

1253a9-15, eserinde bu bağlantıyı yeniden doğrular. Doğanın insana zevk ve acıdan daha fazlasını bahşettiğini ifade ederek, sese sahip olduğunu ima eder, çünkü yalnız insan avantaj ve dezavantajları ortaya koyabilmek için logos'a sahiptir. (Wedin 1988: 146).

Peki, zekâ kavramı nedir? Kökeni hangi döneme dayanmaktadır? Logos ile ilişkisi nedir? $\mathrm{Bu}$ sorulara verilecek cevaplar akıl ve zekâ arasındaki farklılıkları da belirleyecektir. Intelligence ${ }^{3}$ kelimesinin Türkçe'deki karşılığı zekâ'dır. Köken itibariyle Aristoteles'in edilgin akıl (passive intellect) kavramına denk gelir. Burada ‘denk’ ifadesini kullanıyoruz. Çünkü Antik Yunan'da zekâ ya da intellect sözcüğü insanın neliğini tek başına belirlemediği gibi logos ile eşdeğer tutulamaz. Zekâ sözcügünün temelini Descartes felsefesi oluşturmaktadır. Modern döneme kılavuzluk edecek böylesine radikal bir felsefi yöntemin ortaya çıkmasına, Descartes'in yaşadığı dönemin karmaşık atmosferi neden olmuştur. Rönesans dönemini sonlandıran modern felsefeyi ortaya koyarak insanın kendi bilincinin farkına varmasının gelişimini dönemin içinde bulunduğu dinamikleriyle Toulmin (1990) şöyle anlatır:

Erken 17. Yüzyıl sadece ekonomik ve sosyal bir kriz değil aynı zamanda entelektüel ve ruhsal bir krizdi. Hüküm süren şüphecilik anlayış1 çökmüş, kesinlik anlayışı daha çok benimsenmeye başlamıştı. Bu döneme damgasını vuran Descartes, insan bilgisini "açık, seçik ve kesin" temeller üzerine kurmaya çalışmıştı. Öyle ki kendisi, modern çağın rasyonel felsefesi için bir kalkış noktası olmuştu. Descartes'in felsefesi Hristiyanlığın temel ilkeleriyle ters düşmekteydi. Duyguların yanılabilirliğini kullanarak, deneysel her şeyi kuşku alanına çeker sonra da açık ve seçikliğin kuşku götürmez apaçıklığına başvurur. Bunun sonucunda keşfettiği şey, "sorgulanamaz / kuşku götürmez biricik kesin şey”dir. Descartes'e göre şüphesiz her bilim ampirik (deneye dayalı) incelemeyi gerektirir. Ama bu ampirik faaliyetin amacı Francis Bacon'un dediği gibi "olgusal veriler" yığını değildir; aksine Tanrı'nın yaratıcı eyleminin her bir bilimsel alanda vücut bulduğu "açık ve seçik" idealardır. (Toulmin 1990: 47).

Descartes, yaşadığı dönemin karmaşık ve hantal zihniyetini oluşturan kurallardan yakınarak, kendi yöntemini ortaya koyar ve bunu da tam olarak yerine getirme kararı

\footnotetext{
${ }^{3}$ Intelligence /In'telidz(ə)ns/ kelimesi nous'un alanlarından biri olan edilgin ak1l passive intellect ile ilişkilendirilebilir. Dolayısıyla akla ait olan bir fakültenin unsurudur.
} 
alır. $\mathrm{Bu}$ yöntemlerden ilki; önyargılardan ve aceleden kaçınarak bir şeyin apaçık doğruluğundan emin olmak, ikincisi; problemleri mümkün olan asgari bölümlere ayırarak çözümlemek, üçüncüsü; basitten karmaşığa doğru ilerleyen bir sıra izlemek ve son olarak, adımların eksiksiz bir şekilde ilerlediğinden emin olmak amacıyla kontroller ve sayımlar yapmaktır. (Descartes, 1994: 21-22). Descartes'in yöntemlerinden anlaşılacağı gibi, bölümlere ayırarak çözümlemek bu düşüncenin en temel unsurudur. $\mathrm{Bu}$ düşünce k1lavuzluğunda Descartes, Aristoteles'in aksine, zihin ve bedeni köktenci bir yaklaşımla birbirinden ayırarak bilincin mahiyetini tek boyuta sınırlayarak yeniden belirlemiştir.

Cisim 'uzamlı olan şey' (res extensa), ruh ise 'düşünen şey' (res cogitans)dır. Bu yüzden ruh ile cisim birbirinden özce ayrı olan, temel nitelikleri bakımından birbiriyle uzlaşamayan iki tözdürler: Cisim düşünmez, ruh da yer kaplamaz; bir 'duygu' uzayın herhangi bir yerinde değildir, oysa cisim mutlaka bir 'yer'de bulunur. Bu anlayışı ile Descartes, gerçeği yapıca birbirinden büsbütün başka olan iki bölgeye ayırmış oluyordu. (Gökberk 1993: 238).

Descartes'in bedensel (corporeal) olanı düşünen şeyden ayırması, Aristoteles'te bütünsel olan akıl kavramını zorunlu olarak tek boyuta indirgeyerek sınırlandırmıştır. Kendisinden sonraki beş yüz yıla damgasını vuran Descartes, aslında bu uzun dönemin akıl anlayışını salt zihinsel süreçlerle sınırlandırarak zekâya indirgemiştir. Descartes'in bölümlere ayırarak bilgiye ulaşma yaklaşımı, kendisinden sonraki düşünürlere de ilham kaynağı olmuştur. Bunun örneği ilk sayfalarda sunduğumuz çeşitli sözlüklerdeki akıl ve zekâ kavramlarının müphemliğinde fark edilmektedir. Zekâ sözcüğü, zihinsel süreçlere odaklanan bir yaklaşımla çağdaş düşünürler tarafından aklın yerine kullanılmıştır. Örneğin, Descartes'in ayırmacı yaklaşımı temelinde, çeşitli düşünürler insan zekâsını salt zihinsel süreçler temelinde belirli bölümlere ayırmışlardır. Örneğin; (Spearman) genel zekâ, (Thorndike) sosyal zekâ, (Catell), akışkan ve kristalize zekâ, (Sternberg \& Wagner 1986) akademik ve pratik zekâ, (Levinson) etkileşimsel ve analitik zekâ, (Perkins) sinirsel, deneyimsel ve yansitıcı zekâ,. (Sternberg) yaratıcı zekâ, (Mayer) duygusal zekâ, (Kaufman) sözel ve algisal zekâ, (Gardner) görsel-mekânsal, bedenselkinestetik, müzikal, kişilerarası, kişisel, dilsel ve mantıksal-matematiksel zekâ. 
(Sternberg, \& Kaufman 2011: 108). Zekâ'ya yönelik tanımlara bakıldığında zihin-beden birliğinden uzak, ayrık bölümlerden oluşan bir yaklaşım benimsenmiştir. Zekâ kavramının tarihsel açıdan geçirdiği tanımlanma sürecini örnekler nitelikte daha detaylı bir çalışma Legg S. ve Hutter M. (2006) tarafından gerçekleştirilmiştir. A Collection of Definitions of Intelligence ${ }^{4}$ başlıklı araştırmada zekâ kavramı üzerine 70 civarında tanımın öne sürüldüğ̈̈ anlaşılmaktadır. Bu tanımlar; Genel Tanımlar, Psikolog Tanımları ve Yapay Zekâ Araştırmacısı Tanımları olmak üzere üç grupta toplanmıştır. Genel tanımlar başlığı altında 18 tanım listelenmiştir. Bu tanımlar zekâyı; hafıza, bilgi, tecrübe, anlayış, muhakeme, hayal gücü ve genel zihinsel yetenekler olarak temsil etmektedir. Psikolog tanımları ise otuz 34 tanımı içerir. Bu tanımların ortak yönü ise tanımların psikologlar tarafından ortaya konulması ve duyum, algı, ilişkilendirme, hafıza, hayal gücü, ayırt etme, yargı ve muhakeme gibi bilişsel süreçlerden oluşmasıdır. Ayrıca, bilişsel süreçlerin; edinme, bellekte saklama, geri getirme, birleştirme, karşılaştırma sürecinin sonucunda; bilgi ve kavramsal becerileri yeni bağlamlarda kullanabilme adımlarından meydana geldiği öne sürülmektedir. Yapay Zekâ Araştırmacısı Tanımları ise zekâ kavramını hesaplamalı (computational) yönlerden değerlendirmektedir. Bu başlık altında McCarthy J., Minsky M., Nakashima H., Newell A., Simon H. A., Poole D. ve Kurzweil R. gibi Yapay Zekâ'yı teknik yönleriyle ele alan kişilerin tanımlarına yer verilmiştir. Bu başlık zekâ kavramını; dünyevi hedeflere ulaşma yeteneğinin hesaplamalı bir parçası olarak görülür. Bu yönüyle; canlı veya cansız bir öznenin çok çeşitli ortamlarda hedeflere ulaşma yeteneğini bilgiyi işleme kapasitesi olarak ölçer.

Legg S. ve Hutter M. tarafından yönetilen çalışma açıkça göstermektedir ki, farklı düşünürler zekâ terimini öznel yaklaşımlarıyla tanımlamaya girişmişlerdir. Bu girişimin felsefi temelini Descartes'in çözümleme yöntemi oluşturmaktadır. Dolayısıyla, tanımların geneli incelendiğinde iki yaklaşım dikkat çekmektedir. Birincisi zihin-beden ilişkisini birbirinden ayrı tutmak, ikincisi ise tarihselliği olan akıl kavramının

\footnotetext{
${ }^{4}$ https://arxiv.org/abs/0706.3639: erişim tarihi: 13.01.2019.
} 
niteliklerini zekâya yüklemektir. Yani, zekâ terimini akılla eşdeğer tutmak, hatta zekây1 akı1 karşısında daha gözde bir konuma yerleştirme ülküsündedir.

Akıl ve Zekâ kavramları üzerine yaptığımız felsefi sorgulama açıkça ortaya koymaktadır ki; bu kavramların ayrımı, konumu ve birbiriyle ilişkisi gözden kaçmış ya da hafife alınmıştır. Ancak, her iki kavramın felsefi kökleri insani değerlerin, düşünsel ve davranışsal niteliklerin gelecekteki sonucunu haber vermektedir. Akıl kavramının ortaya çıktığı dönem ile günümüz dünyasında akla yüklediğimiz anlam arasında büyük bir uçurum vardır. Bu boşluk Aristoteles ve birçok İlkçağ düşünürünün akıl hakkında paylaştı̆̆ görüşler karşısında modern felsefenin akıl sözcügünü, zekâ adında yeniden tanımla girişimiyle ortaya çıkmıştır. Aristoteles insanı zihin-beden birliğiyle anlar. Bu bağlamda ne zihin beden karşısında ne de beden zihin karşısında birbirine egemenlik kurar. "Amaç ise; isteğin düşünceyi takip etmesidir. Öyleyse hem ak1l yürütme doğru olmalı hem de istek haklı çıkmalıdır. Yani eylemlerimiz tercihlerimizden, tercihlerimiz de isteklerimizden meydana gelir." (Aristotle 1893: 180-184). Bunun yanı sira Aristoteles, aklın tarihselliğine yani deneyime vurgu yapar. Bu bağlamda, genç birisinin zorlu matematik sorularını çözebileceği ama aklıselim olabilmenin, yılların meyvesini tatmış tecrübeli kişilere mahsus olduğunu iddia eder.

Rönesans'ın buhranlı son dönemlerinde keşfettiği yöntemiyle akıl kavramını derinden etkileyen Descartes, bugün zekâ olarak tabir ettiğimiz terimin doğmasina neden olmuştur. Bu kavram aklın niteliklerini sınırlandırdığı gibi, modern felsefenin coşkulu analizleriyle akıldan daha üstün bir konuma taşınmıştır. Modernliğin ilerleme zannedildiği dünyamızda içten içe gerileyen, daralan zekâ kavramı; insani nitelikleri, toplumsal dinamikleri ve evrensel değerleri derinden sarsmıştır. Bu süreç bir üçgenin tepe noktasındaki dar açıya benzer; daima yüksekte, keskin, sivri ancak dar, sınırlı ve korkutucudur. Bu daralma en yalın haliyle, "Yapay Zekâa" gibi teknolojik ilerlemelere rağmen, insani değerlerin gerilemesi olarak düşünülebilir. Gelişmekte olan bu sürecin sorumlusu; Kartezyen modern felsefe anlayışıdır. Çözümleyici anlayışın kavramların 
Ferhat BAYIK, “Aristoteles ve Descartes Bağlamında Akıl ve Zekâ Kavramlarının Farkları,” Kaygı, 18(1)/2019: 172-187.

içini boşaltmasının en ciddi nedeni, bütünselliği ya da birliği dağıtarak birbirinden kopuk kavramlar geliştirmesidir. Diğer bir deyişle, bütünden parçalar oluşturması ve nihayetinde parçaları bütün karşısında egemen kılmaya çalışmasıdır. Netice itibariyle, insani niteliklerin belirlenmesinde ölçüt zekâ değil akıl olmalıdır. "İnsan nedir?" sorusunun cevabı zekâ sözcüğünün darlığında değil, en geniş haliyle akıl tabanında karşılık bulabilecektir. 


\section{KAYNAKÇA}

ARISTOTLE (1893). The Nichomachean Ethics of Aristotle. trans. F. H. Peters, Kegan Paul, Trench, Truebner \& Co. Yayınlar1.

ARİSTOTELES (2014). Nikomakhos'a Etik, çev. F. Akderin , İstanbul: Say

AYGÜN, Ö. (2017). The Middle Included: Logos in Aristotle, Northwestern University Press.

DESCARTES, R. (1994). Metot Üzerine Konuşma, çev. K. Sahir Sel, İstanbul: Sosyal Yayınları.

FURLEY, D. (1997). From Aristotle to Augustine, Routledge.

GIRARD, D. (1965). Cassell's New French-English Dictionary, London: Cassell \& Co. Ltd.

GÖKBERK, M. (1993). Felsefe Tarihi, İstanbul: Remzi Kitabevi.

KELLY, D. R. (2017). The Descent of Ideas: The History of Intellectual History, New York: Routledge.

KERFERD, G. B. (1967). "Logos”, Encyclopedia of Philosophy, Volume 5.

LEGG, S. ve HUTTER, M. (2006). A Collection of Definitions of Intelligence https://arxiv.org/abs/0706.3639. Erişim Tarihi: 13.01.2019.

LONG, A. A. (1986). Hellenistic Philosophy Stoics, Epicureans, Sceptics, University of California Press.

ROSS, W. D., Smith J. A., MURE ve diğerleri (1908). The Works of Aristotle, Oxford: The Clarendon Press.

ROSS, W. D. (1995). Aristotle, New York: Routledge.

ROSS. W. D. (2011). Aristoteles, İstanbul: Kabalcı Yayınevi.

STERNBERG, R. J \& KAUFMAN S. B. (2011). The Cambridge Handbook of Intelligence, Cambridge University Press.

TOULMIN, S. (1990). The Hidden Agenda of Modernity, The University of Chicago Press.

URIARTE C.; CAÑEQUE, S. T. ve SUNAL, C. B (2010) Diccionario TurcoEspañol, Navalcarnero.

ÜLKÜ, V. (2005) Büyük Almanca- Türkçe Sözlük, İstanbul: İnk1lap Yayınevi.

WEBSTER, M. (1986). Webster's Third New International Dictionary, USA. 
Ferhat BAYIK, "Aristoteles ve Descartes Bağlamında Akıl ve Zekâ Kavramlarının Farkları," Kaygl, 18(1)/2019: 172-187. Press.

WEDIN, M. V. (1988). Mind and Imagination in Aristotle, Yale University 